\title{
Improvement Approach for Matching PV-array and Inverter of Grid Connected PV Systems Verified by a Case Study
}

\author{
Moien A. Omar* and Marwan M. Mahmoud \\ Electrical Engineering Department, An-Najah National University, Nablus, West Bank, Palestine
}

\begin{abstract}
Correct matching between PV array and inverter improves the inverter efficiency, increases the annual produced energy, decreases the clipping losses of the inverter, and prevent to a large extent the inverter frequent shut downs during clear sunny days of high solar radiation and low ambient temperature. Therefore, this paper presents a new methodology for selecting the appropriate peak power of the PV array with respect to the inverter output AC rated power taking into account the local daily distribution of solar radiation and ambient temperature. In addition, the proposed methodology specifies the appropriate number of PV modules in each string and the number of parallel strings connected to the input of the inverter according to its specifications and to PV cell temperature. Mathematically modeling of system parameters and components are presented and used in the simulation to investigate the different scenarios. The paper presents also a case study using simulation to find the optimal matching parameters of a PV array connected to an inverter with the specifications: $6 \mathrm{~kW}$ rated output power, an input mpp voltage range of 333-500 V, $6.2 \mathrm{~kW}$ maximum input DC power, and an output AC voltage of 230 Vrms. Considering the local climate conditions in West Bank, the simulation resulted a peak power of $7 \mathrm{~kW}$ for the PV array, which is greater than the inverter output power by the factor 1.16. In addition, the obtained PV array consists of two parallel strings each includes $12 \mathrm{PV}$ modules connected in series while each PV module is rated at $290 \mathrm{~W}$. The output voltage of the PV array varies between $359 \mathrm{~V}$ to $564 \mathrm{~V}$ at minimum and maximum temperature of $10{ }^{\circ} \mathrm{C}$ to $70{ }^{\circ} \mathrm{C}$ respectively. This $\mathrm{PV}$ array-inverter combination resulted by simulation an annual yield of $1600 \mathrm{kWh} / \mathrm{kWp}$ and an energy of $11197 \mathrm{kWh}$ which corresponds to an energy gain of 1591 $\mathrm{kWh} /$ year more than using a PV array with a peak power of $6 \mathrm{~kW}$ as the inverter rated power.
\end{abstract}

Keywords: PV grid connected systems; PV inverters; PV array inverter sizing ratio; maximum power point; PV array configuration.

Article History: Received: $25^{\text {th }}$ January 2021; Revised: 25 ${ }^{\text {th }}$ March 2021; Accepted: $8^{\text {th }}$ April 2021; Available online: $20^{\text {th }}$ April 2021

How to Cite This Article: Omar, M.A. and Mahmoud, M.M. (2021) Improvement Approach for Matching PV-array and Inverter of Grid Connected PV Systems Verified by a Case Study. International Journal of Renewable Energy Development, 10(4), 687-697 https://doi.org/10.14710/ijred.2021.36082

\section{Introduction}

During the last three decades, the attention of scientists and researchers has been concentrated on global challenges such as depletion of fossil fuels, global warming and public health dangers posed by air pollution. As a result, governments and policymakers were instigated to consider the renewable energy resources as an effective possible solution. Solar photovoltaic (PV) power systems became the most widely owned electrical sources in the world due to the continuous cost degradation of PV modules and to the increase of the solar PV cell efficiency (Honrubia et al. 2018). The European Photovoltaic Industry Association (EPIA) reported that the total cumulative installed PV capacity in the world exceeded $138.8 \mathrm{GW}$ in 2013 (EPIA 2014) and at the end of 2016 amounted to at least $303 \mathrm{GW}$ (Brunisholz 2015). The recent challenge is to make $\mathrm{PV}$ systems competitive to the conventional power sources that generate electricity by fossil fuels. This goal could be achieved by reducing the cost of PV system components (PV modules and PV inverters), as well as by improving the conversion efficiency. The PV systems efficiency improvement leads to increase the PV energy production, which results in reducing the payback period and thereby encourages the investors to install more PV systems. The PV-conversion efficiency of grid-connected PV systems depends on climatic factors, inverters technical characteristics, PV modules parameters, array orientation and wires used for interconnecting the different parts of PV systems.

The inverter efficiency has attracted the attention of researches and engineers because it represents the most important factor which affects the overall efficiency of the PV systems. The PV inverters in the market are available with different categories, depending on the input DC side like module inverters, string inverters, and central inverters. Also depending on the output AC side of single phase or three phase inverters. The PV inverters are designed with transformer or without transformers. The commonly used inverters are with two conversion stages as illustrated in Fig.1. The first stage is the DC/DC converter used for maximum power tracking (MPPT) and the second is the DC/AC conversion stage used for producing the AC output power with acceptable power quality standards. The inverter losses are associated with losses of semiconductor switching devices used in the inverter.

\footnotetext{
* Corresponding author: youremail@mail.com
} 
The switching losses and conduction losses represent the losses in the inverters. The switching losses are proportional to switching frequency and the conduction losses are associated with the drop voltage across each switch during switching on. The inverter specifications include the ratings of power, voltage and current of both inverter DC and AC sides. In addition, it includes the inverter efficiency curve, which represents the relation between inverter output power and inverter efficiency. The efficiency is maximized when the inverter output power is close to its rated power $\left(\mathrm{P}_{\text {inv,rated }}\right)$ while the lower inverter efficiency occurs when the inverter supplies low power. The inverter input power is proportional to the PV array rated power $\left(\mathrm{P}_{\mathrm{pv}, \text { rated }}\right)$ which is usually given at standard test conditions (STC). The STC main two factors are the PV cell temperature ( $\left.\mathrm{T}_{\mathrm{C}}\right)$ which amounts to $25^{\circ} \mathrm{C}$ and the reference solar radiation $(\mathrm{G})$ which amounts to $1000 \mathrm{~W} / \mathrm{m}^{2}$. In realistic practical conditions, $\mathrm{T}_{\mathrm{C}}$ is higher than $25^{\circ} \mathrm{C}$, while $\mathrm{G}$ can be less than $1000 \mathrm{~W} / \mathrm{m}^{2}$. Therefore, the PV output power decreases at increasing $\mathrm{T}_{\mathrm{C}}$ more than $25^{\circ} \mathrm{C}$ and at decreasing $\mathrm{G}$ below $1000 \mathrm{~W} / \mathrm{m}^{2}$. In case of choosing $\mathrm{P}_{\mathrm{pv}, \text { rated }}$ and $\mathrm{P}_{\mathrm{inv}, \text { rated }}$ to be equal, the inverter will operate at lower conversion efficiency. Therefore, the PV array is purposely designed to have a rated power higher than $\mathrm{P}_{\text {inv,rated }}$ as shown in Fig.1. This makes the inverter to operate closed to its rated power for longer periods and thereby the inverter efficiency is improved. Matching factors of PV array and inverter requires testing the most appropriate peak power and output voltage of the PV array (Camps et al. 2015). The inverter loading ratio is discussed by (Jeremy and Johnson 2016) and the sizing ratio $R_{s}$ is discussed by (Wang et al. 2018). $R_{s}$ is commonly defined as the ratio of $\mathrm{P}_{\mathrm{pv}, \text { rated }}$ over $\mathrm{P}_{\text {inv,rated }}\left(\mathrm{R}_{\mathrm{s}}=\mathrm{P}_{\mathrm{pv}, \text { rated }}\right.$ $/ \mathrm{P}_{\text {inv,rated }}$ ), it is considered to be a major factor affecting the annual DC/AC conversion efficiency (Good and Johnson 2016; Wang et al.2018). Usually, the PV array is selected so that $R_{\mathrm{s}}>1$ in order to capture more PV energy during low solar radiation or cloudy conditions and to increase the utilization of PV inverter (Burger and Ruther 2008). In case the PV array is undersized, the PV system has $R_{\mathrm{s}}$ less than 1 , this leads to increase the periods where the inverter operates at low input power and therefore at lower conversion efficiency. In addition, selecting an appropriate $R_{\mathrm{s}}$ value would always prevent the PV array to produce a $\mathrm{DC}$ power exceeding the inverter rated power even during periods of best climate conditions in winter months (sunny days of high solar radiation and low ambient temperature) and thereby inverter shutting off is avoided. During summer months the produced PV array power is always less than the inverter rated power due to relatively high losses caused by high ambient temperature. Due to the importance of choosing the correct ratio $R_{\mathrm{s}}$ on the PV output energy, $R_{\mathrm{s}}$ has attracted considerable attention in the literature (Burger and Ruther 2008; Wang et al. 2018).

The advantages of making $\mathrm{P}_{\mathrm{pv}, \text { rated }}$ higher than $\mathrm{P}_{\text {inv,rated }}$ with the impact of increasing $R_{\mathbb{S}}$ on the energy yield and energy cost for different climates and array orientations are discussed by (Peippo and Lund 1993). The same analysis has been carried out for sites with different climate conditions (Rodrigo et al. 2016). The analysis to determine the optimum $R_{\mathrm{S}}$ were proposed by (. (Mondol et al. 2006) the study found that $\mathrm{R}_{\mathrm{s}}$ for low and high solar radiation locations should be within 1.3-1.4 and $1.1-1.2$, respectively.
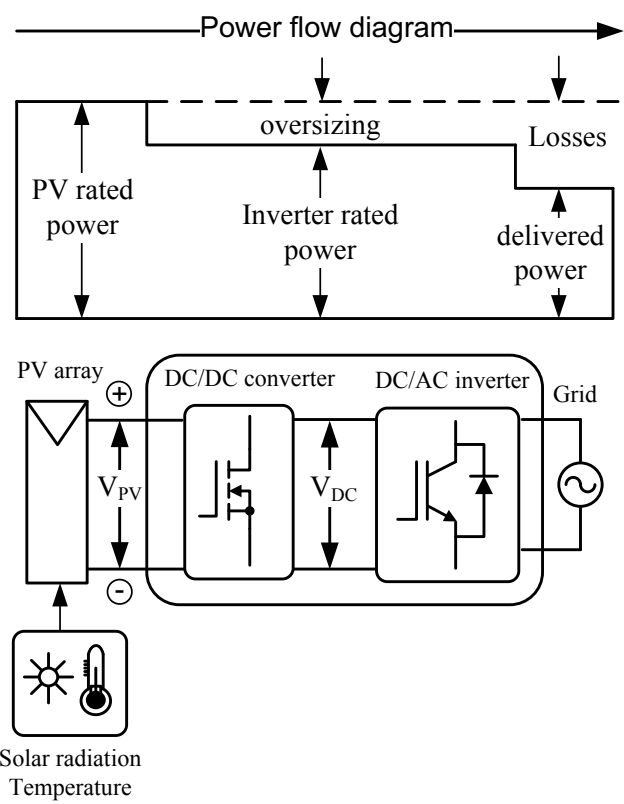

Fig.1 Power flow diagram of grid connected PV system (Blaabjerg 2018)

Various factors that influence the inverter sizing strategy (Chen et al. 2013). The study focused on the meteorological, economic, and inverter characteristic factors. The economic analysis of increasing the captured PV energy and saving in the inverter cost due to over sizing the PV (Faranda et al. 2015). In some cases, with high $R_{\mathrm{s}}$ the inverter is forced to clip the output power or to shut down. The clipping occurs by shifting the maximum power point to limit the inverter output power so that it does not exceed $P_{\text {inv,rated. This action causes clipping losses }}$ that contributes in reducing the overall efficiency of PV systems (Wang et al. 2018). In case, the input inverter power exceeds the maximum specified DC inverter input power $\left(\mathrm{P}_{\mathrm{DC}-\max }\right)$ due to high $\mathrm{R}_{\mathrm{s}}$ ratio, frequent inverter shutdowns occur at high solar radiation and low temperature. Therefore, PDC-max must be considered as an important parameter for finding the correct $R_{\mathrm{S}}$ ratio which is missing in the aforementioned papers. Moreover, the attention of researchers (Chen et al. 2013; Faranda et al. 2015) focused on the PV array rated power with respect to inverter rated power apart from discussing the importance of determining the output DC voltage of the PV array which should be within the specified input voltage range of the inverter. Therefore, this paper is focusing on determining the correct number of PV modules connected in series in one PV string adequate to the inverter specified input voltage range.

The PV array voltage (VPV) is the input inverter voltage as shown in Fig. 1 varies mainly according to $\mathrm{T}_{\mathrm{C}}$, which continuously varies according to ambient temperature $\left(\mathrm{T}_{\mathrm{A}}\right)$ and $\mathrm{G}$. It depends also on other factors as the type of PV modules, and the quality of internal wiring between the PV modules. Therefore, it is necessary to select the correct array configuration to keep $\mathrm{V}_{\mathrm{PV}}$ variation within the specified inverter mpp voltage range $\left[\mathrm{V}_{\text {inv-mpp }(\min )}\right.$ to

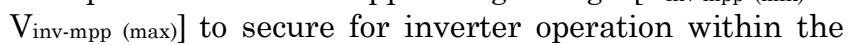
mpp mode.

The findings of this paper propose a methodology for matching the PV array and the inverter to increase the 
annual energy generated and therefore improve the DC/AC conversion efficiency. The rated power of PV array, with respect to inverter rated power, is discussed first considering the $\mathrm{P}_{\mathrm{DC}-\max }$ and propose a modified accurate model for the inverter efficiency curve. This paper also discusses how to select the appropriate PV array output power and voltage to keep it within the DC inputs specifications of the inverter. Furthermore, it presents a case study in West Bank- Palestine to verify the proposed matching methodology by using Matlab and PVsyst programs. The obtained results can be used for other places with similar climatic conditions.

\section{Modelling and description of PV system components}

Mathematical modelling of system parameters and the PV system components consisting of PV array and inverter are discussed in this section.

\subsection{The PV array parameters}

The PV array is the major part of the grid connected PV system, it consists of PV modules connected in series and parallel depending on module voltage, PV module rated peak power, and inverter specifications. The performance of PV cell depends on weather conditions represented mainly in cell temperature and solar radiation.

The PV cell temperature $\mathrm{T}_{\mathrm{C}}$ cannot be directly measured because the PV cells in a module are usually not accessible, it can be estimated by Eq.(1) which is the most widely used considered model (Santiago et al. 2018).

$$
\mathrm{T}_{\mathrm{C}}=\mathrm{T}_{\mathrm{A}}+\left(\frac{\mathrm{G}}{800}\right) \times(\text { NOCT }-20)
$$

where $\mathrm{T}_{\mathrm{A}}$ is the ambient temperature in $\left({ }^{\circ} \mathrm{C}\right), \mathrm{G}$ the solar radiation intensity $\left(\mathrm{W} / \mathrm{m}^{2}\right)$ on the $\mathrm{PV}$ module surface and NOCT is the nominal operating cell temperature in $\left({ }^{\circ} \mathrm{C}\right)$ that depends on the design and construction materials of the PV module, typically it is in the range from 43 to 48 ${ }^{\circ} \mathrm{C}$. The peak watt or PV rated power of PV modules is specified by manufacturers and measured under STC. The STC stand for an irradiance of $1000 \mathrm{~W} / \mathrm{m}^{2}$, an atmospheric mass (AM) of 1.5 solar spectrums and a PV cell temperature of $25^{\circ} \mathrm{C}$. However, in practice the $\mathrm{STC}$ are rarely obtained over a year. Therefore, to estimate the output power, voltage and current of the PV array, it is important to consider the following equations:

The open circuit voltage (VOC) of PV cell drops substantially by increasing $\mathrm{T}_{\mathrm{C}}$ as expressed in Eq. (2) (Masters 2013; Jatoi et al 2018).

$$
\mathrm{V}_{\mathrm{OCT}}=\mathrm{V}_{\mathrm{OC}(\mathrm{STC})} \times\left[1+\mathrm{k}_{\mathrm{V}}\left(\mathrm{T}_{\mathrm{C}}-25\right)\right]
$$

where $V_{\text {OCT }}$ is the cell open circuit voltage at the temperature $\mathrm{T}_{\mathrm{C}}, \mathrm{V}_{\mathrm{OC}(\mathrm{STC})}$ the open circuit voltage of the cell at STC and $\mathrm{kV}$ is the temperature coefficient of open circuit voltage. The $\mathrm{kV}$ has negative values between $-0.30 \% /{ }^{\circ} \mathrm{C}$ and $-0.55 \% /{ }^{\circ} \mathrm{C}$ for crystalline silicon modules (Omar and Mahmoud 2019).

In the contrary, the short circuit current (Isc) of the PV cell increases only negligible very little by increasing the temperature $\mathrm{T}_{\mathrm{C}}$ according to Eq. (3),

$$
\mathrm{I}_{\mathrm{SCT}}=\mathrm{I}_{\mathrm{SC}(\mathrm{STC})} \times\left[1+\mathrm{k}_{\mathrm{i}}\left(\mathrm{T}_{\mathrm{C}}-25\right)\right]
$$

where ISCT $_{\text {is }}$ the cell short circuit current at the temperature $\mathrm{T}_{\mathrm{C}}\left({ }^{\circ} \mathrm{C}\right), \mathrm{I}_{\mathrm{SC}}$ (STC) is the short circuit current of the cell at STC and $k_{i}$ is the temperature coefficient of short circuit current. $\mathrm{k}_{\mathrm{i}}$ is positive with values between $+0.02 \% /{ }^{\circ} \mathrm{C}$ and $+0.08 \% /{ }^{\circ} \mathrm{C}$ for crystalline silicon modules (Premkumar et al. 2020).

The output power of PV module (PPV) for any solar radiation on the PV surface (GPV) and any cell temperature $\left(\mathrm{T}_{\mathrm{C}}\right)$ is calculated by Eq. (4) (Notton et al. 2010).

$$
\mathrm{P}_{\mathrm{PV}}=\mathrm{P}_{\mathrm{PV}, \mathrm{STC}} \times\left[1+\mathrm{k}_{\mathrm{mpp}} \times\left(\mathrm{T}_{\mathrm{C}}-25\right)\right] \times \frac{\mathrm{G}_{\mathrm{PV}}}{\mathrm{G}_{\mathrm{STC}}}
$$

where, $k_{m p p}$ is the temperature coefficient of maximum power point, it has a negative value in the range between - $0.4 \% /{ }^{\circ} \mathrm{C}$ and $-0.48 \% /{ }^{\circ} \mathrm{C}$ for commercially crystalline silicon. $\mathrm{P}_{\mathrm{PV}, \mathrm{STC}}$ is peak watt and $\mathrm{G}_{\mathrm{STC}}$ is the solar radiation amounting to $1000 \mathrm{~W} / \mathrm{m}^{2}$ (Sánchez-Carbajal, \& Rodrigo. 2019; Jatoi et al 2020). The voltage at maximum power point $\mathrm{V}_{\mathrm{mpp}}$ is determined by Eq.(5).

$$
\mathrm{V}_{\mathrm{PV}-\mathrm{mpp}}=\mathrm{V}_{\mathrm{PV}-\mathrm{mpp}(\mathrm{STC})} \times\left[1+\mathrm{k}_{\mathrm{mpp}}\left(\mathrm{T}_{\mathrm{C}}-25\right)\right]
$$

The coefficient $\mathrm{k}_{\mathrm{mpp}}$ is used in Eq. (4) because the data sheets of PV module lack always for $\mathrm{V}_{\mathrm{mpp}}$ temperature coefficients. Therefore, using $\mathrm{k}_{\mathrm{mpp}}$ is closer to righteousness of using the $\mathrm{kV}$ because the current variation with temperature is minimal and therefore the maximum voltage and maximum power coefficients vary approximately with same amounts. The most common PV modules used commercially at present consist of 60 and 72 cells. These modules are preferable to use due to their high rated power (more than $100 \mathrm{~W}$ ) and high output voltage. The price per watt peak for these modules is less than the price related to PV modules with low rated power and cells number. Moreover, the PV inverter requires relatively high input DC voltage which means in case of using PV modules of 36 cells more PV modules should be connected in series which requires more connectors and more cost. The PV modules specifications given in data sheets at STC present $V_{\text {OC }}$ values in the range of 0.6 to $0.65 \mathrm{~V}$ per cell for crystalline silicon. On the other hand, $\mathrm{V}_{\mathrm{mpp}}$ varies from (0.506 to 0.508$) \mathrm{V}$ per cell. The current values of Isc and $I_{\text {mpp }}$ depend on the PV cell area, for ISC it varies from (3240) $\mathrm{mA}$ per $\mathrm{cm}^{2}$ for crystalline silicon.

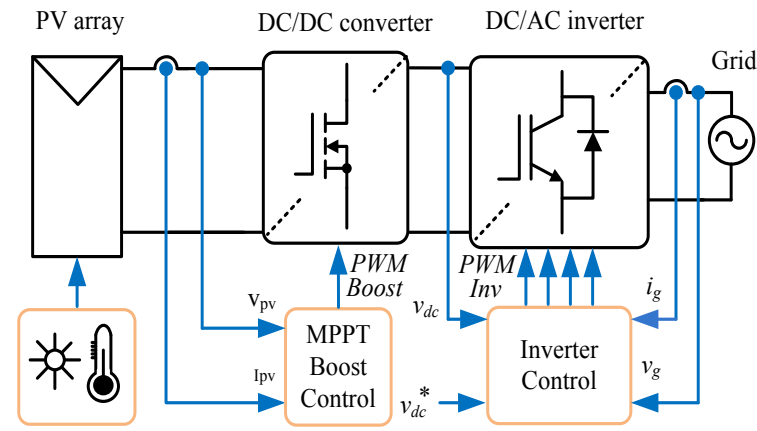

Solar radiation

Ambient temperature

Fig.2 PV grid connected system components and control (Blaabjerg 2018) 


\subsection{The PV inverters}

The grid connected PV system illustrated in Fig.2 consists of two conversion stages. The first stage consists of a DC/DC converter used for maximum power point tracking (MPPT) and to boost the voltage of PV array to be suitable for the second conversion stage (DC/AC). The inverter input DC voltage, inverter rated power and inverter efficiency are discussed in this section.

\subsubsection{Inverter DC input voltage}

The inverter DC voltage $\left(\mathrm{V}_{\mathrm{DC}}\right)$ must be carefully selected depending on the inverter output voltage. In single phase transformer-less inverters the required $\mathrm{V}_{\mathrm{DC}}$ is calculated by Eq. (6) where $\mathrm{V}_{\text {rms }}$ is the output voltage of the inverter and $\mathrm{M}_{\mathrm{a}}$ is the modulation index. It is not recommended to select $\mathrm{M}_{\mathrm{a}}$ to be more than 1 , since it will result in increasing the total harmonic distortion (THD) of the inverter output voltage (Mohan and Undeland 2007). Therefore, by considering $\mathrm{M}_{\mathrm{a}}=1$ in Eqs. $(6,7)$ the minimum required $V_{D C}$ can be obtained for inverters which use sine pulse width modulation (SPWM) (Holmes et al. 2003).

$$
\begin{gathered}
V_{r m s}=\frac{V_{D C}}{\sqrt{2}} \times M_{a} \\
V_{r m s}(L L)=\sqrt{\frac{3}{2}} \times \frac{V_{D C}}{2} \times M_{a}
\end{gathered}
$$

For single phase inverters of output voltage $\mathrm{V}_{\mathrm{rms}}=230 \mathrm{~V}$ the minimum required $\mathrm{V}_{\mathrm{DC}}$ amounts to $325 \mathrm{~V}$. For three phase inverter with line voltage $\mathrm{V}_{\mathrm{rms}}$ of $400 \mathrm{~V}$, the minimum required $\mathrm{V}_{\mathrm{DC}}$ amounts to $653 \mathrm{~V}$. It is worth noting that the required $\mathrm{V}_{\mathrm{DC}}$ for three phase inverter is higher than the required $V_{D C}$ for single phase inverters. The safety margins of selecting $V_{D C}$ must be considered because the voltage drop may occur in the inverter output filter and inverter components (Mohan and Undeland 2007). The voltage $V_{D C}$ is controlled and remains constant by an inverter controller and $\mathrm{Vpv}$ varies depending on $\mathrm{T}_{\mathrm{C}}$ and $\mathrm{G}$ as shown in Fig.2. Therefore, the controller tracks the current IPV and the voltage VPV and keep them at maximum values by changing the duty ratio of $\mathrm{DC} / \mathrm{DC}$ converter respecting the MPPT algorithms.

The inverter input voltage specifications given in data sheets include the mpp voltage range and the maximum input DC voltage $\mathrm{V}_{\mathrm{DC} \text {-max }}$. The designer must choose the string voltage to remain always within the mpp input voltage range of the inverter and not to exceeds $\mathrm{V}_{\mathrm{DC} \text {-max. }}$

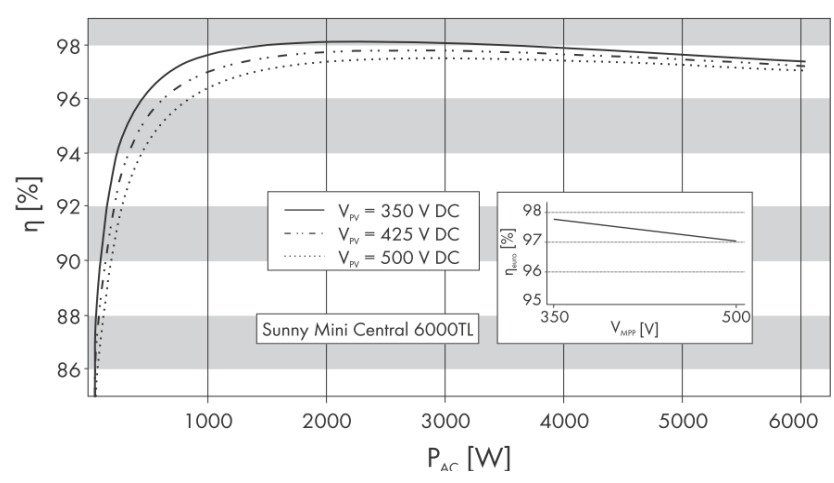

Fig.3 The efficiency curve of $6 \mathrm{~kW}$ single phase inverter

\subsubsection{Inverter rated power}

The rated powers of the inverter includes $\mathrm{P}_{\mathrm{DC}-\max }$, and the maximum $\mathrm{AC}$ output power $\left(\mathrm{P}_{\text {inv,rated }}\right)$. In case, the inverter input power exceeds the $\mathrm{PDC}_{\mathrm{DC}}$ ax the inverter will shutdown. On the other hand, the inverter will limit its output power to not exceeding the $\mathrm{P}_{\text {inv,rated. }}$

\subsubsection{Inverter efficiency}

The inverter efficiency depends on its input DC power generated from the PV array, which depends on solar radiation and PV-cell temperature. The efficiency curve of PV inverter shows the relation of inverter efficiency with its output power as shown in Fig.3. It can be observed that, the efficiency reaches its maximum value when the inverter delivers about $40 \%$ of its nominal power. The efficiency also depends on the input voltage VPV. Therefore Fig. 3 illustrates the efficiency at different input voltages.

\subsubsection{Model of inverter efficiency curve}

The main purpose of modeling the inverter efficiency curve is to calculate the inverter AC output power from the DC input power generated from the PV array. In literature, different approaches are used to model the inverter efficiency curve to obtain the output AC power of the inverter ( $\left.\mathrm{P}_{\mathrm{AC}}\right)$. The proposed model by (Camps et al. 2015) used the inverter specifications which includes the nominal inverter powers of $\mathrm{AC}$ and $\mathrm{DC}$ sides at nominal operating conditions. It includes also the minimum power at the DC side required to start the inversion process and the parameters defining the parabolic curvature of the relationship between $\mathrm{P}_{\mathrm{AC}}$ and $\mathrm{P}_{\mathrm{DC}}$. This model requires parameters that does not exist in the inverter specifications which makes it difficult to use. (King et al 2007) proposed the relationship between $P_{A C}$ and $P_{D C}$ to be nearly linear. However, this linear equation does not exactly determine the correct values of $\mathrm{P}_{\mathrm{AC}}$. The proposed model for the inverter efficiency curve in this paper represents a linear relation between $\mathrm{P}_{\mathrm{DC}}$ and $\mathrm{P}_{\mathrm{AC}}$ at different inverter power levels. The curve splits into more than one region in order to make the model more accurate than the model presented by (Boyson, et al 2007). The $\mathrm{P}_{\mathrm{AC}}$ can be calculated by Eq. (8) where the coefficients $\mathrm{k}_{1}$ and $\mathrm{k}_{2}$ are extracted from the inverter efficiency curve by using curve fitting tool in Matlab as will be discussed in the next sections. $P_{A C}$ is not allowed to exceed the $P_{\text {inv,rated }}$ because the inverter limits the output power to the rated power and clips the excess power by shifting the mpp point. The excess power represents the clipping losses that can be calculated from Eq. (9).

$$
\begin{gathered}
\mathrm{P}_{\mathrm{AC}}= \begin{cases}\mathrm{k}_{1} * \mathrm{P}_{\mathrm{DC}}+\mathrm{k}_{2} & \mathrm{P}_{\mathrm{AC}} \leq \mathrm{P}_{\text {inv }, \text { rated }} \\
\mathrm{P}_{\text {inv,rated }} & \mathrm{P}_{\mathrm{AC}}>\mathrm{P}_{\text {inv,rated }}\end{cases} \\
\mathrm{P}_{\text {clipping }}= \begin{cases}0 & \mathrm{P}_{\mathrm{AC}} \leq \mathrm{P}_{\text {inv,rated }} \\
\mathrm{P}_{\mathrm{AC}}-\mathrm{P}_{\text {inv,rated }} & \mathrm{P}_{\mathrm{AC}}>\mathrm{P}_{\text {inv,rated }}\end{cases}
\end{gathered}
$$

\subsubsection{Inverter maximum input power}

The maximum DC input power $\left(\mathrm{P}_{\mathrm{DC}-\max }\right)$ of the inverter is given in the inverter data sheets where it is recommended to keep the input power to be less than $\mathrm{P}_{\mathrm{DC}}$ 
max in order to avoid inverter frequent shutdowns where the inverter needs few minutes to start up again which leads to more losses over the year. This design constraint is very important to consider especially in the case of increasing the $\mathrm{P}_{\mathrm{pv}, \text { rated }}$ to be higher than $\mathrm{P}_{\text {inv,rated }}$. The PPV. $\mathrm{R}$ is the PV array rated power required to generate the PDC-max, it is calculated by Eq. (10),

$$
\mathrm{P}_{\mathrm{PV}-\mathrm{R}}=\frac{\mathbf{P}_{\mathrm{DC}-\mathrm{max}}}{\left[1+\mathrm{k}_{\mathrm{mpp}} \times\left(\mathrm{T}_{\mathrm{C}-\mathrm{m}}-25\right)\right] \times \frac{\mathrm{G}_{\mathrm{PV}-\mathrm{m}}}{\mathrm{G}_{\mathrm{STC}}}}
$$

where GPV-m is the hourly average of maximum solar radiation $\left(\mathrm{W} / \mathrm{m}^{2}\right)$ in a month and $\mathrm{T}_{\mathrm{C}-\mathrm{m}}\left({ }^{\circ} \mathrm{C}\right)$ is the average cell temperature for each month in a year. The PPV-R is minimum when solar radiation is high and ambient temperature is low. On the other hand, at high solar radiation and high temperature the $\mathrm{P}_{\mathrm{PV}-\mathrm{R}}$ is maximum. The rated power of the PV array must be less than or equal the PPV-R (minimum) in order to avoid the inverter frequently shutdowns in months with high solar radiation and low temperature where the PV generated power is higher due to low $\mathrm{T}_{\mathrm{C}}$.

\section{PV array inverter matching methodology}

This section discusses the proposed methodology for matching the PV array with the inverter. It includes determining the correct peak power of PV array and the configuration or interconnections of PV modules considering the inverter input voltage and current constraints.

\subsection{Selecting the PV array rated power}

The PV array rated power must be calculated depending on weather data, inverter specifications and inverter efficiency model descried in section 2. Figure 4 illustrates the flowchart to calculate the correct PV array rated power. The simulation was performed for a complete year. The PV array rated power is considered initially to be the inverter nominal power, then it is increased stepwise with $\Delta \mathrm{p}$ in each simulation loop without exceeding PPv-R (minimum) which calculated by Eq. (10).

The value of annual output energy and the annual energy yield $\mathrm{kWh} / \mathrm{kWp}$ are calculated for each loop, then the PV power with maximum $\mathrm{kWh} / \mathrm{kWp}$ is selected to be the optimum PV array rated power.

\subsection{PV array DC side matching}

After obtaining the correct rated power of the PV array, the next step is to consider the selected inverter DC ratings and determine the rated power of each PV module, the number of PV modules and the interconnections between these modules.

The connection of PV modules in series forms the PV string, while the connection of strings in parallel forms a PV array as shown in Fig.5. $\mathrm{V}_{\mathrm{PV}}$ is equal to the string voltage which amounts to module voltage $\left(\mathrm{V}_{\mathrm{m}}\right)$ multiplied by number of modules in series $\left(\mathrm{N}_{\mathrm{S}}\right)$. The PV array current (IPV) is the current of one string multiplied by number of parallel strings $\left(\mathrm{N}_{\mathrm{p}}\right)$.

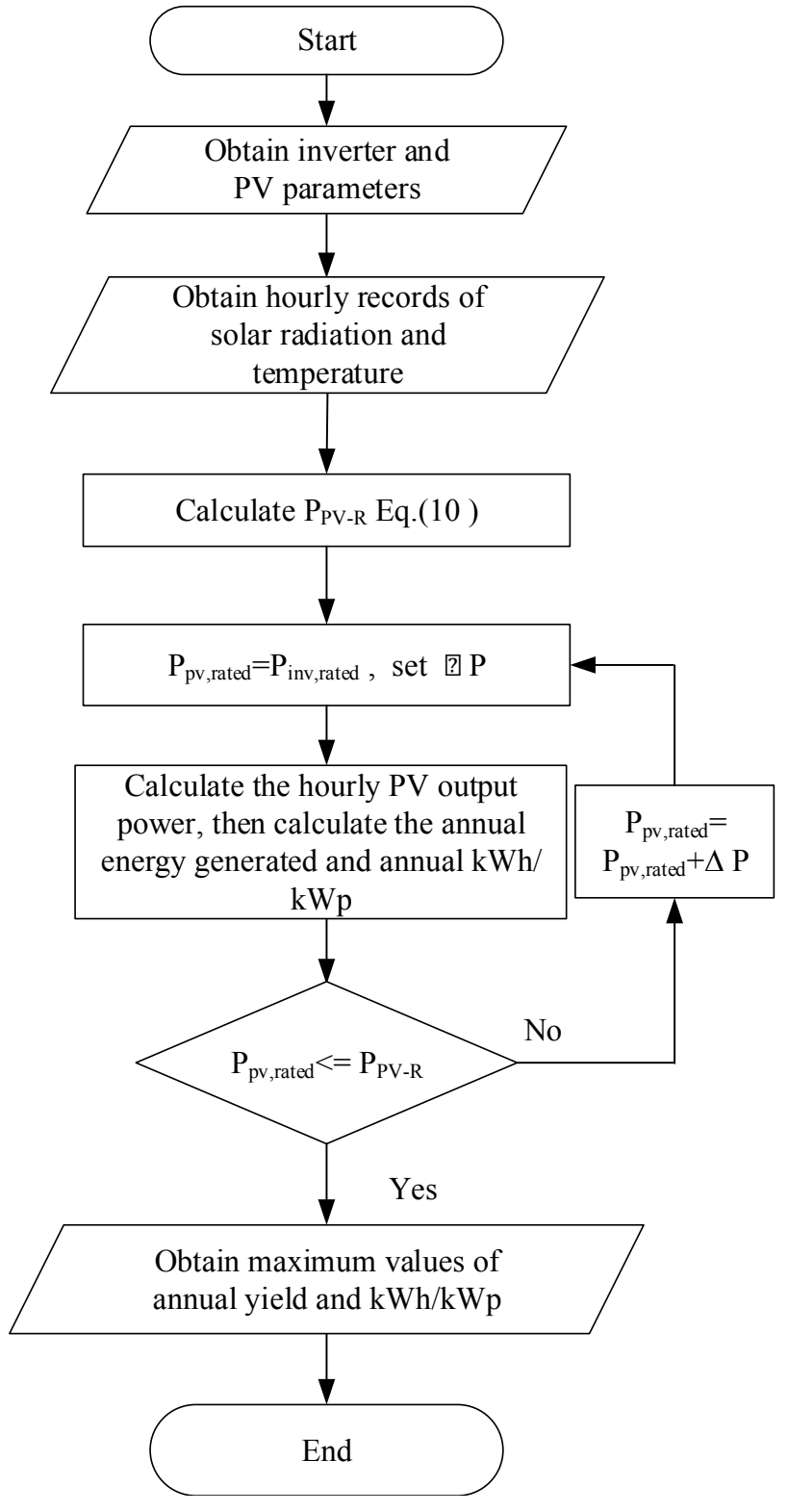

Fig.4 Flow chart for calculating $\mathrm{P}_{\mathrm{PV}, \text { rated }}$

The maximum value of array voltage $\mathrm{V}_{\mathrm{PV} \text {-max }}$ can be calculated by Eq. (11), it must be lower than the inverter maximum input voltage $\left(\mathrm{V}_{\text {inv-max }}\right)$.

$$
\mathrm{V}_{\mathrm{PV}-\max }=\mathrm{Ns} \times\left[\mathrm{V}_{\mathrm{OC}-\mathrm{STC}} \times\left(1+\mathrm{k}_{\mathrm{V}}\left(\mathrm{T}_{\mathrm{C}-\text { min }}-25\right)\right)\right]
$$

where VOC-STC is the open circuit voltage of PV module at STC, $\mathrm{T}_{\mathrm{C}-\mathrm{min}}$ is the minimum cell temperature which occurs during PV system operation, where the voltage of the PV module is maximum at low cell temperature. The reason of considering the $\mathrm{V}_{\mathrm{OC}}$ because it represents the maximum voltage of the PV module.

The voltage at maximum power point of the PV array

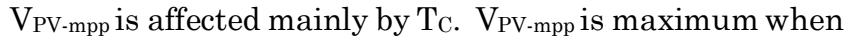
$\mathrm{T}_{\mathrm{C}}$ is minimum and it is minimum when $\mathrm{T}_{\mathrm{C}}$ is maximum as in Eqs. $(12,13)$. VPV-mpp must be maintained within the mpp range of the inverter [ $\mathrm{V}_{\text {inv-mpp (min) }}$ to $\mathrm{V}_{\text {inv-mpp (max) }}$ ] as in Eq.(14) in order to insure correct operation of MPPT controller. 


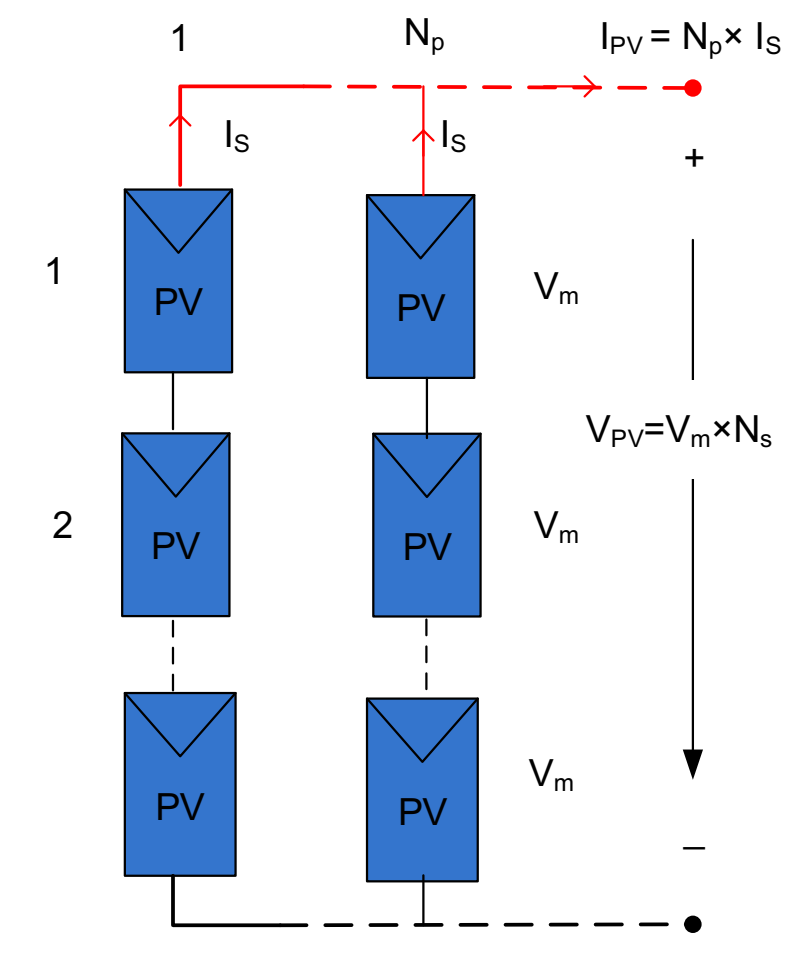

Fig.5 PV array interconnections

$$
\begin{gathered}
\mathrm{V}_{\mathrm{PV}-\mathrm{mpp}(\min )}=\mathrm{N}_{\mathrm{s}} \times\left[\mathrm{V}_{\mathrm{PV}-\mathrm{mpp}(\mathrm{STC})} \times\left(1+\mathrm{k}_{\mathrm{mpp}}\left(\mathrm{T}_{\mathrm{C}-\mathrm{max}}-25\right)\right)\right] \\
\mathrm{V}_{\mathrm{PV}-\mathrm{mpp}(\max )}=\mathrm{N}_{\mathrm{s}} \times\left[\mathrm{V}_{\mathrm{PV}-\mathrm{mpp}(\mathrm{STC})} \times\left(1+\mathrm{k}_{\mathrm{mpp}}\left(\mathrm{T}_{\mathrm{C}-\text { min }}-25\right)\right)\right] \\
\mathrm{V}_{\text {inv-mpp(min) }} \leq \mathrm{V}_{\mathrm{PV}-\mathrm{mpp}} \leq \mathrm{V}_{\text {inv-mpp }(\max )}
\end{gathered}
$$

The maximum and minimum number of series modules $\mathrm{N}_{\text {s-max }}$ and $\mathrm{N}_{\mathrm{s} \text {-min }}$ is calculated by Eqs. $(16,17)$. The maximum current of PV array (IPV-max) must not exceed the maximum inverter DC input current IDC-max as shown in Eq. (15).

$$
\begin{gathered}
\mathrm{I}_{\mathrm{PV}-\text { max }}=\mathrm{N}_{\mathrm{p}} \times\left[\mathrm{I}_{\mathrm{SC}(\mathrm{STC})} \times\left(1+\mathrm{k}_{\mathrm{i}}\left(\mathrm{T}_{\mathrm{C}-\max }-25\right)\right)\right] \\
\mathrm{N}_{\mathrm{s}-\max }=\mathrm{V}_{\mathrm{inv}-\operatorname{mpp}(\max )} / \mathrm{V}_{\mathrm{PV}-\operatorname{mpp}(\max )} \\
\mathrm{N}_{\mathrm{s}-\text { min }}=\mathrm{V}_{\text {inv-mpp(min) }} / \mathrm{V}_{\mathrm{PV}-\operatorname{mpp}(\min )}
\end{gathered}
$$

The non-integer values of calculated $\mathrm{N}_{\text {s-min }}$ and $\mathrm{N}_{\text {s-max }}$ round up and round down respectively.

\section{Case study and practical example}

In this section, the proposed methodology is verified in a case study using weather data of West-Bank, Palestine. The PV array rated power and its output voltage are selected with respect to a single phase inverter specification.

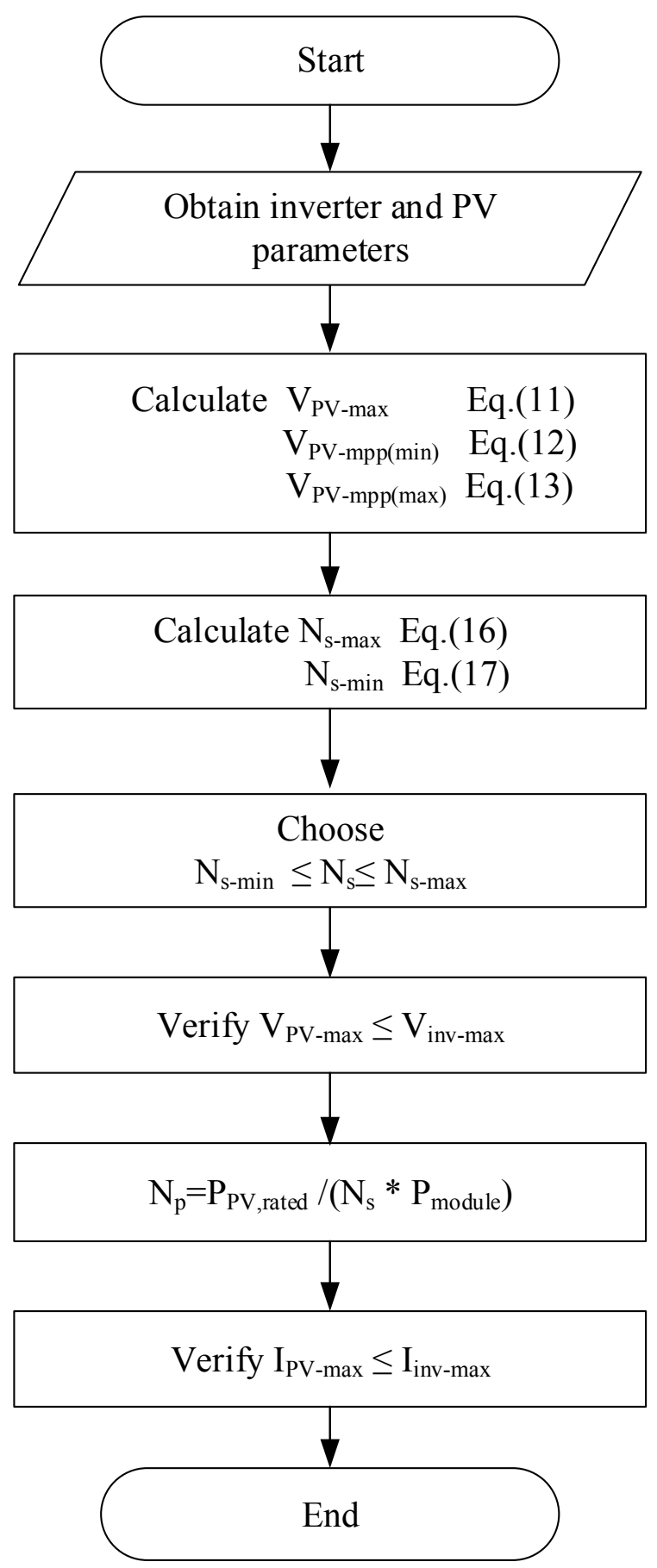

Fig.6 Flow chart for determining PV array configuration

Table 1

Specifications of the inverter used in the case study Rated power / max. apparent power AC $6 \mathrm{~kW} / \mathrm{kVA}$ $\mathrm{P}_{\mathrm{DC}-\max } \cos \phi=1 \quad\left(\mathrm{P}_{\mathrm{DC}}\right) \quad 6,200 \mathrm{~W}$ Maximum DC voltage (VDC max) $700 \mathrm{~V}$ mpp voltage range $\left(\mathrm{V}_{\mathrm{mpp}}\right) \quad 333 \mathrm{~V}-500 \mathrm{~V}$ DC nominal voltage $\left(\mathrm{V}_{\mathrm{DC}}\right.$ nom $)$

Minimum DC voltage ( $\left.\mathrm{V}_{\mathrm{DC}} \mathrm{min}\right)$ $350 \mathrm{~V}$

Maximum input current ( $\left.\mathrm{I}_{\mathrm{PV} \max }\right) \quad 19.0 \mathrm{~A}$

Total harmonic factor THD (\%) 


\subsection{Inverter specifications}

The selected inverter for the case study is type sunny boy $6000 \mathrm{TL}$ with the specification illustrated in Table 1. Selecting the appropriate rated power of a PV array requires to calculate the annual energy yield for each simulation loop, then the correct rated PV power can be selected when the maximum energy yield is achieved. In each simulation loop $\mathrm{P}_{\mathrm{DC}}$ is calculated by considering $\mathrm{G}$, $\mathrm{T}_{\mathrm{C}}$ and $\mathrm{P}_{\mathrm{PV}}$,rated then by using the inverter efficiency curve $\mathrm{P}_{\mathrm{AC}}$ is calculated. The relation between $\mathrm{P}_{\mathrm{AC}}$ and the efficiency represented in the original efficiency curve as shown in Fig.3. In order to determine the relation between $\mathrm{P}_{\mathrm{DC}}$ and $\mathrm{P}_{\mathrm{AC}}$, the curve is divided into three regions $\mathrm{A}, \mathrm{B}$, and $\mathrm{C}$ as shown in Fig.7, where the points of the output power and efficiency are extracted to calculate the relation between $\mathrm{P}_{\mathrm{DC}}$ and $\mathrm{P}_{\mathrm{AC}}$ for each region. The relation between $\mathrm{P}_{\mathrm{DC}}$ and $\mathrm{P}_{\mathrm{AC}}$ are represented in linear curve of coefficients $\mathrm{k}_{1}$ and $\mathrm{k}_{2}$ as illustrated in Eq. (8). The coefficients $\mathrm{k}_{1}$ and $\mathrm{k}_{2}$ are calculated by using curve fitting tool as illustrated in Table 2. Fig. 7 shows that, the proposed model exactly represents the original curve of the selected inverter.

\subsection{Available data for the analysis}

The PV array output power $\mathrm{P}_{\mathrm{DC}}$ is calculated for each hour by using hourly solar radiation and ambient temperature in northern West-bank of Palestine. Palestine has main two figures to indicate the high potential of solar energy. First the annual average of solar radiation intensity on horizontal surface which amounts to $5.4 \mathrm{kWh} / \mathrm{m}^{2}$-day and second the sunshine duration which amounts to about 3000 hours/year (Omar and Mahmoud 2018). Fig. 8 shows the monthly average of daily solar energy intensity measured on tilted surface in Nablus area - Palestine (Omar and Mahmoud 2019). As seen in Fig.8, the average of solar energy measured on tilted surface $\left(32^{\circ}\right)$ in Nablus area during the eight months: March-October amounts to $6.82 \mathrm{kWh} / \mathrm{m}^{2}$-day while it amounts to $3.14 \mathrm{kWh} / \mathrm{m}^{2}$-day for the remaining four months: November-February.

Different studies have shown that the annual yield of $1 \mathrm{kWp}$ PV system varies in the range of $1600-1800$ $\mathrm{kWh}$ /year (Omar and Mahmoud 2019). The temperature during PV system production varies from low values during winter months Dec., Jan. and Feb. to high values during summer months Jun., Jul. and Aug. where the maximum ambient temperature reaches $32.5^{\circ} \mathrm{C}$ in July.

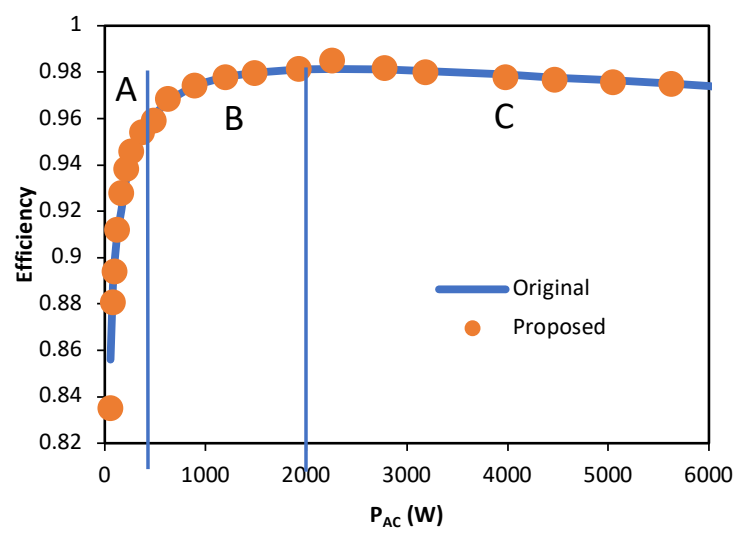

Fig.7 Inverter efficiency curve with proposed model
Table 2

The coefficients of the inverter curve

\begin{tabular}{ccc}
\hline Power range (watt) & $\mathrm{k}_{1}$ & $\mathrm{k}_{2}$ \\
\hline$P_{D C}<500$ & 0.9753 & -7.9462 \\
$500 \leq P_{D C}<2000$ & 0.9875 & -11.956 \\
$2000 \leq P_{D C}$ & 0.9683 & 36.826 \\
\hline
\end{tabular}

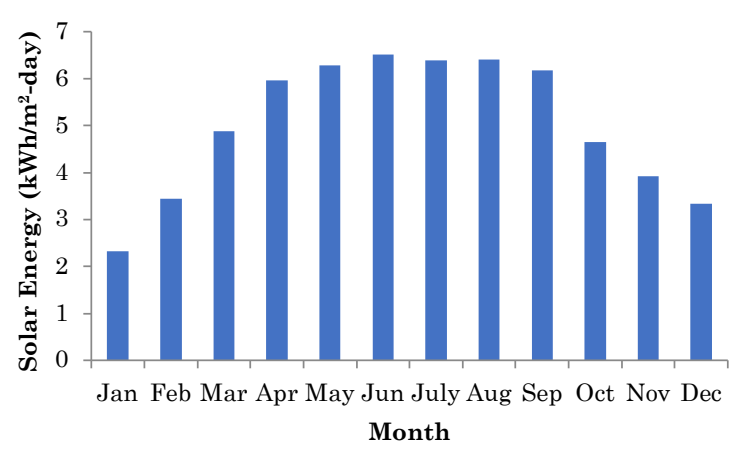

Fig.8 Monthly average of solar energy intensity

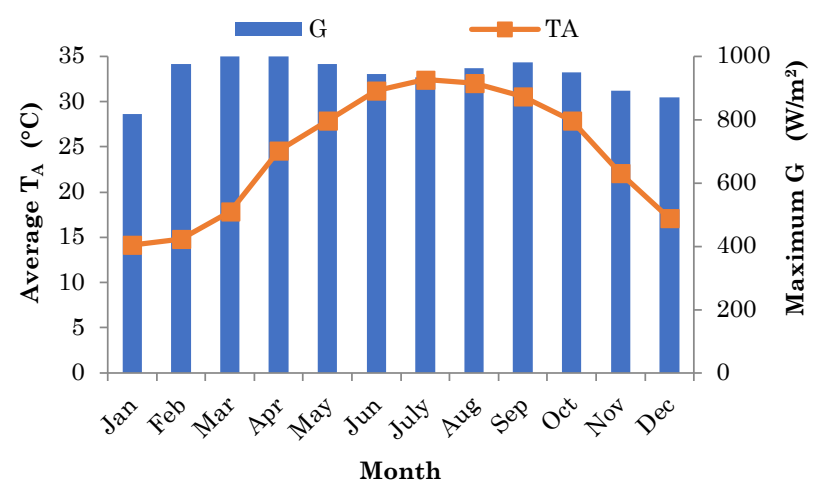

Fig.9 Maximum measurements of $\mathrm{G}\left(\mathrm{W} / \mathrm{m}^{2}\right)$ and average $\mathrm{T}_{\mathrm{A}}\left({ }^{\circ} \mathrm{C}\right)$.

Figure 9 shows the maximum solar radiation measured over the months of the year with the average ambient temperature for each month during sunshine hours. It can be observed that, the temperature during PV system production varies from low values during winter months Dec., Jan. and Feb. to high values during summer months Jun., Jul. and Aug. where the maximum ambient temperature reaches $32.5^{\circ} \mathrm{C}$ in July.

\subsection{Implementation of the proposed matching criteria}

The first step according to flowchart in Fig.4 is determining the rated power of the PV array P PV-R by Eq. (10) using the maximum inverter power $\mathrm{P}_{\mathrm{DC}-\max }$ of $6200 \mathrm{~W}$ and data of solar radiation and temperature shown in Fig.9. The obtained values for each month are tabulated in Table 3 and shown in Fig.10. It can be observed that, the minimum $\mathrm{P}_{\mathrm{PV}-\mathrm{R}}$ amounts to $7 \mathrm{kWp}$ occurs in March due to low temperature and high solar radiation, while PPV-R amounts to $7.83 \mathrm{kWp}$ due to higher temperature in August. This is the main reason since the solar radiation in both months are very close as shown in Fig. 11. 
Citation: Omar, M.A. and Mahmoud, M.M. (2021) Improvement Approach for Matching PV-array and Inverter of Grid Connected PV Systems Verified by a Case Study. Int. Journal of Renewable Energy Development, 10(4), 687-697, doi: 10.14710/ijred.2021.36082

$\mathrm{P}$ a g e 1694

Table 3

The PV rated power required to generate $\mathrm{PDC}_{\mathrm{m} \text { max }}$ of the inverter at different conditions.

\begin{tabular}{ccccc} 
Month & $\mathbf{T}_{\mathbf{A}}\left({ }^{\circ} \mathrm{C}\right)$ & $\mathbf{T}_{\mathbf{C}}\left({ }^{\circ} \mathbf{C}\right)$ & $\mathbf{G}\left(\mathbf{W} / \mathrm{m}^{2}\right)$ & $\mathbf{P}_{\mathbf{P V}-\mathbf{R}}(\mathbf{W})$ \\
\hline Jan & 14.14 & 39.67 & 816.87 & 8.16 \\
Feb & 14.84 & 45.32 & 975.29 & 7.04 \\
Mar & 17.89 & 49.14 & 1000 & 7.01 \\
Apr & 24.57 & 55.82 & 1000 & 7.28 \\
May & 27.89 & 58.35 & 974.83 & 7.57 \\
Jun & 31.23 & 60.75 & 944.86 & 7.92 \\
July & 32.45 & 61.63 & 933.62 & 8.06 \\
Aug & 32.04 & 62.16 & 963.87 & 7.83 \\
Sep & 30.55 & 61.23 & 981.62 & 7.65 \\
Oct & 27.86 & 57.52 & 949.12 & 7.74 \\
Nov & 22.07 & 49.96 & 892.56 & 7.89 \\
Dec & 17.14 & 44.31 & 869.61 & 7.86 \\
\hline
\end{tabular}

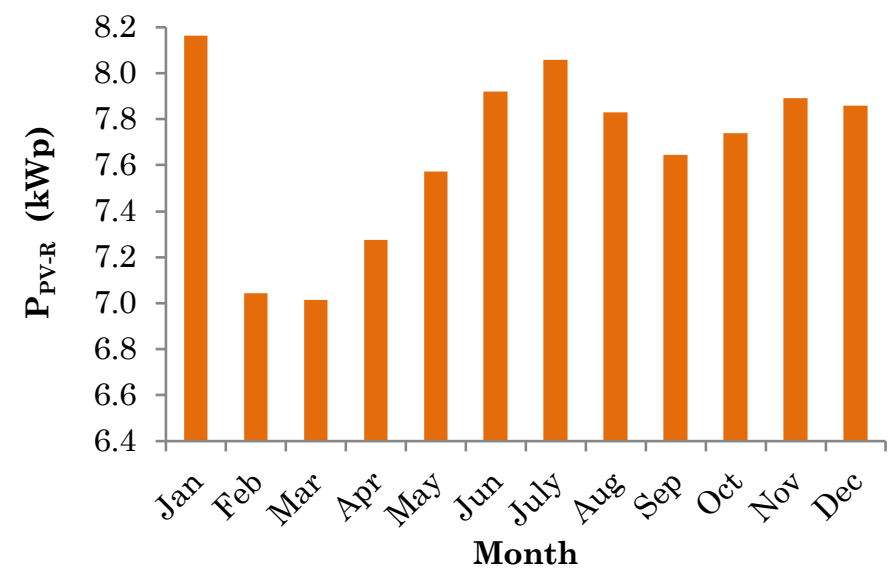

Fig.10 The required PV peak power to generate the maximum inverter DC input power for each month

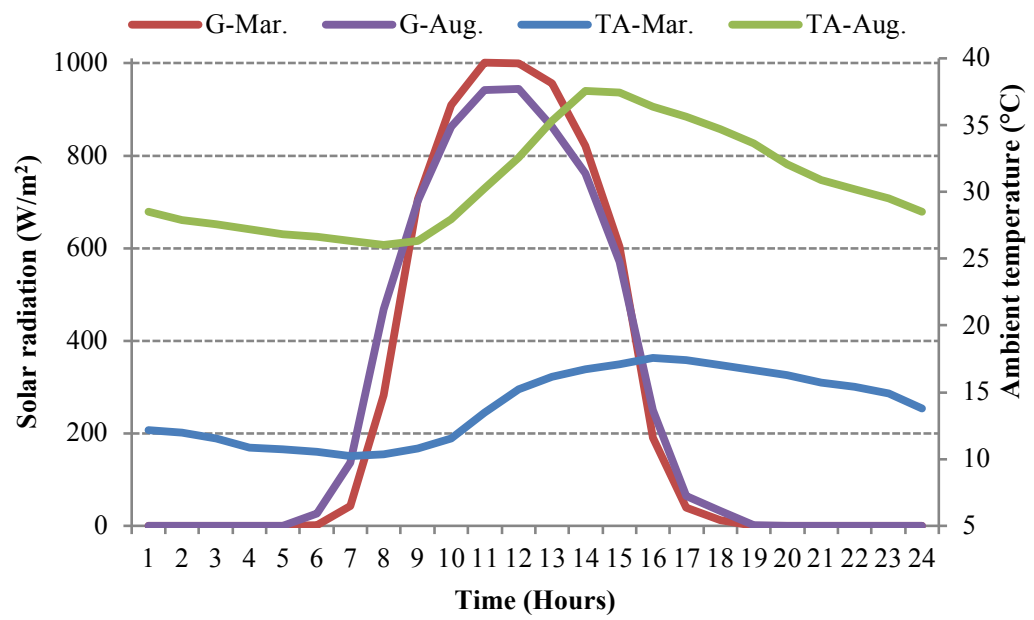

Fig.11 Hourly measurements of $\mathrm{G}$ and $\mathrm{T}_{\mathrm{A}}$ for two clear days in March and August. 


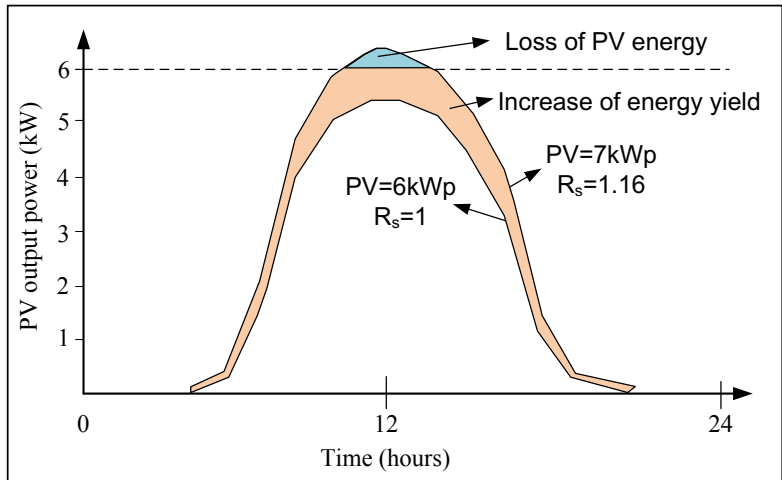

Fig.12 Hourly output AC power delivered from $6 \mathrm{kWp}$ and $7 \mathrm{kWp}$ PV arrays during a clear sunny day in March

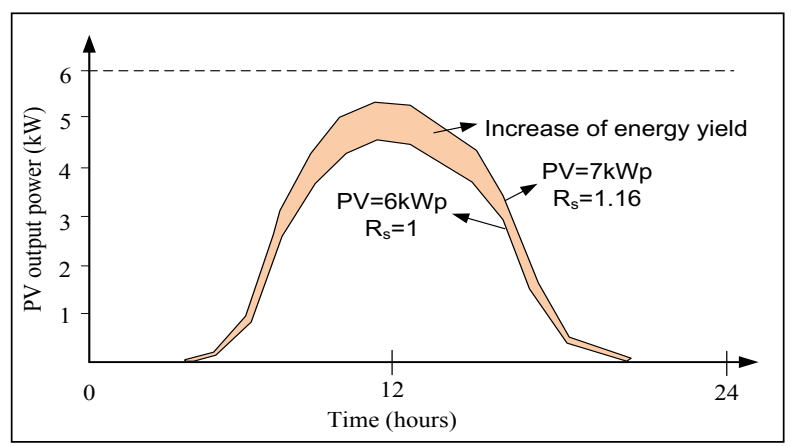

Fig.13 Hourly output AC power delivered from $6 \mathrm{kWp}$ and $7 \mathrm{kWp}$ PV arrays during a clear sunny day in August.

Fig.12 shows the hourly output power of the inverter in a clear day in March where the ambient temperature is lower than in August. It can be observed that, by increasing the peak power of the PV array from $6 \mathrm{kWp}$ to $7 \mathrm{kWp}$ the energy gains in a sunny day amounts to 5.57 $\mathrm{kWh}$ while the clipping losses amount to $0.35 \mathrm{kWh}$. Comparing the above results with those of August shown in Fig.13, where the temperature losses are more, the daily energy gain amounts to $5.44 \mathrm{kWh}$ and no clipping losses are registered.

Hourly simulation for a complete year was performed power step wise amounting to $200 \mathrm{~W}$, starting from inverter rated power of $6 \mathrm{kWp}$ to the minimum value of $\mathrm{P}_{\mathrm{PV}-\mathrm{R}}=7 \mathrm{kWp}$ obtained in Table 4 , this is to reduce the shutting off time of the inverter. In each simulation loop the annual energy production is calculated as shown in Fig 14. It can be observed that the annual energy generated is increased by increasing the PV rated power. For example, in case the PV rated power is $6 \mathrm{kWp}$, the annual energy production amounts to $9606 \mathrm{kWh}$ while it amounts 11,197 $\mathrm{kWh}$ for PV of $7 \mathrm{kWp}$. It is worth noting that the annual yield $\mathrm{kWh} / \mathrm{kWp}$ is approximately constant for all scenarios and amounts to $1600 \mathrm{kWh} / \mathrm{kWp}$. Therefore, the saving is only in the inverter cost where we can use an inverter of $6 \mathrm{~kW}$ for a PV system of $7 \mathrm{kWp}$. After selecting the appropriate $\mathrm{PV}$ array rated power it is important to match the PV array configuration to be compatible with the inverter DC side specifications. In this part, the flow chart illustrated in Fig.6 is used to determine the number of series PV modules in one PV string, number of parallel strings and the PV module rated power. PV modules with 72 cells are selected because they are common to use more than other module types.
According to inverter specifications given in Table 1, the maximum input voltage of the inverter amounts to $700 \mathrm{~V}$ and its mpp voltage range is between 333 to $500 \mathrm{~V}$. The cell temperature range during the $\mathrm{PV}$ system operation varies from $10{ }^{\circ} \mathrm{C}$ in winter to $70^{\circ} \mathrm{C}$ in summer. The temperature coefficients of crystalline PV modules are $\mathrm{k}_{\mathrm{mpp}}=-0.4 \% /{ }^{\circ} \mathrm{C}, \mathrm{k}_{\mathrm{v}}=-0.31 \% /{ }^{\circ} \mathrm{C}$, and $\mathrm{k}_{\mathrm{i}}=0.05 \% /{ }^{\circ} \mathrm{C}$. It is

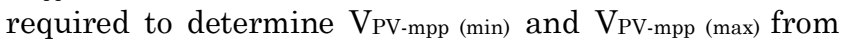
Eqs. (12) and (13) respectively. The minimum voltage occurs at high cell temperature $\left(70^{\circ} \mathrm{C}\right)$ is $29.93 \mathrm{~V}$. The maximum voltage occurs at low cell temperature $\left(10^{\circ} \mathrm{C}\right)$ is $38.69 \mathrm{~V}$. The maximum and minimum number of series modules $\mathrm{N}_{\mathrm{s}-\max }$ and $\mathrm{N}_{\mathrm{s}-\min }$ are calculated by Eqs. $(16,17)$.

$\mathrm{N}_{\mathrm{s}-\min }=333 / 29.9=11.13$ rounded up to 12 Modules.

$\mathrm{N}_{\mathrm{s}-\max }=500 / 38.69=12.9$ rounded down to 12 modules.

In this case both values are equal but in cases they are different we recommend to choose $\mathrm{N}_{\text {s-max }}$ in order to increase the voltage and therefore reduce the voltage drop in the system. The VPV-max is calculated by Eq. (11) as $46.987 \mathrm{~V} \times 12=564 \mathrm{~V}$ which is less than the specified maximum voltage of the inverter amounting to $700 \mathrm{~V}$.

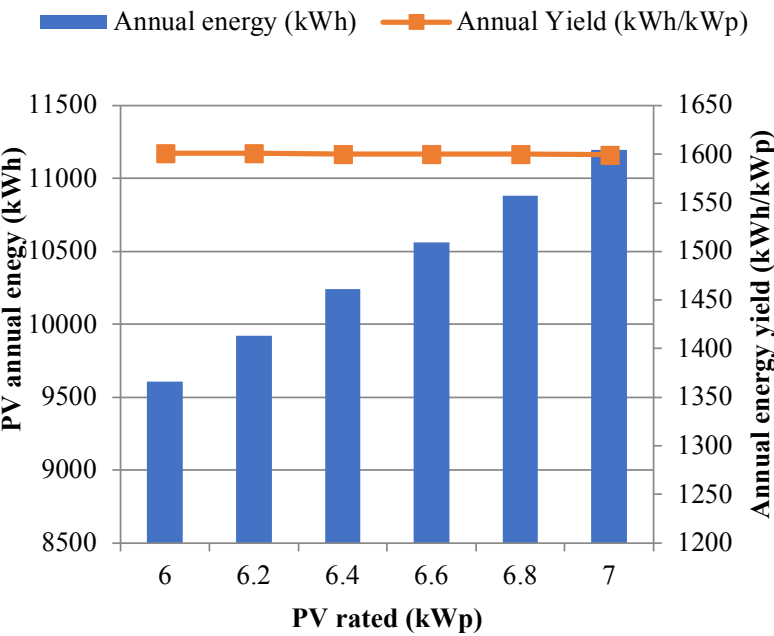

Fig.14 Annual energy generated and annual yield

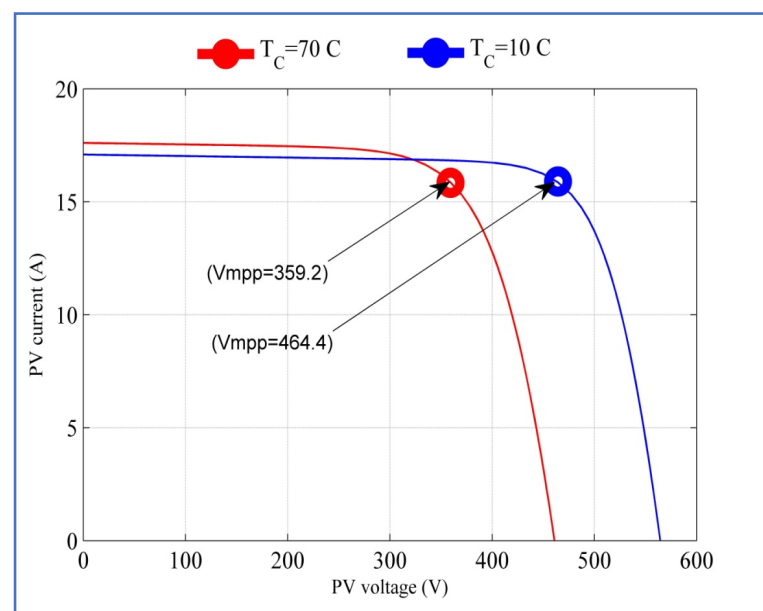

Fig.15 The I-V characteristic curve of the PV array

The peak power of a PV module in a string is calculated by dividing the PV array rated power by $\mathrm{N}_{\mathrm{s}}\left(7000 / 12 \mathrm{xN}_{\mathrm{p}}\right)$ with $\mathrm{N}_{\mathrm{p}}$ integer, in case $\mathrm{N}_{\mathrm{p}}=1$ the module rated power amounts 
to $583.3 \mathrm{~W}$ which is not available in the market. Therefore, we should choose the next integer $\mathrm{N}_{\mathrm{p}}=2$ in order to decrease the PV module peak power to a value available in the world market. By choosing $\mathrm{N}_{\mathrm{p}}=2$ then we have 2 string each has 12 modules where each module is rated at 290W.

In practice it is preferred to reduce the number of parallel strings in order to reduce the losses of circulating currents between the PV strings. Therefore, we recommend to start with $\mathrm{N}_{\mathrm{p}}=1$, if the module is not available then choose $\mathrm{N}_{\mathrm{p}}=2$ and so on. The short circuit current $\mathrm{I}_{\mathrm{SC}(\mathrm{STC})}$ of the selected PV module amounts to 8.38 A. The maximum current of the selected PV array, calculated by Eq. (15), amounts to $17.137 \mathrm{~A}$ which is less than the maximum inverter current amounting to $19 \mathrm{~A}$. Fig. 15 shows the IV curve of the above specified PV array obtained by using PVsyst simulation software at $\mathrm{G}=1000$ $\mathrm{W} / \mathrm{m}^{2}$ with minimum and maximum cell temperatures, $\mathrm{T}_{\mathrm{C}}$ $=10^{\circ} \mathrm{C}$ and $70^{\circ} \mathrm{C}$ respectively. These results are very close to the obtained calculation results which verifies the effectiveness of the proposed design approach.

\section{Conclusion}

The correct matching between PV array and inverter improves the overall efficiency of the PV system and prevents inverter shutdowns. The matching requires considering the inverter specifications at DC and AC sides to determine the correct PV array rated power and the appropriate PV array output voltage and current. The correct configuration of PV array makes the PV array output voltage under all climate conditions to be always between the minimum and maximum input voltage of the inverter specified by the manufacture. The findings of this paper propose a methodology for matching the PV array and the inverter to increase the annual energy generated and therefore improve the DC/AC conversion efficiency. The rated power of $\mathrm{PV}$ array with respect to inverter rated power is discussed first considering the $\mathrm{P}_{\mathrm{DC}-\max }$ and proposing a modified accurate model for the inverter efficiency curve. This paper also discusses how to select the appropriate PV array output power and voltage to keep it within the DC inputs specifications of the inverter. This paper presents a case study in West Bank- Palestine to verify the proposed matching methodology and the obtained results can be used for other places with similar climatic conditions. The presented case study, which combines a PV array of $7 \mathrm{~kW}$ peak power with an inverter of $6 \mathrm{~kW}$ rated power $\left(\mathrm{R}_{\mathrm{s}}=1.16\right)$, resulted an annual energy gain of $1591 \mathrm{kWh}$ higher than using a PV array of $6 \mathrm{~kW}$ peak power. It resulted also an energy gain of $5.57 \mathrm{kWh}$ and $5.44 \mathrm{kWh}$, during clear sunny days in March and August respectively, in comparison to the case where the PV array has the same power as the inverter. Moreover, clipping energy losses amounting to $0.35 \mathrm{kWh}$ /day were registered at solar noon time during a clear sunny day in March which is an indicator for negligible clipping losses amount during the whole winter months, since clear sunny days are seldom or very limited during winter. The hourly simulation for a complete year resulted that the annual yield of different PV array ratings starting from 6 $\mathrm{kWp}$ to $7 \mathrm{kWp}$ are very close. The simulation results show that choosing of $R_{\mathrm{s}}$ ratio with the value of 1.16 will result in increasing the output energy of the PV inverter to deliver an annual energy yield amounting to 1600 $\mathrm{kWh} / \mathrm{kWp}$. The used configuration in the case study example consists of two PV strings in parallel where each string consists of 12 modules connected in series while each PV module has 72 cells connected in series with a rated power for the PV module of $290 \mathrm{~W}$. The simulation results show that the string voltage remains under all working conditions within the mpp voltage range specified by the inverter manufacture. This power and voltage matching resulted in obtaining the maximum possible active power from the inverter.

\section{References}

Blaabjerg, F. (Ed.). (2018). Control of Power Electronic Converters and System, (2). Academic Press. doi:10.1016/c2015-0-02427

Boyson, W. E., Galbraith, G. M., King, D. L., \& Gonzalez, S. (2007). Performance model for grid-connected photovoltaic inverters. (No. SAND2007-5036). Sandia National Laboratories. doi:10.2172/920449

Brunisholz, G. (2015)."Snapshot of Global Photovoltaic Markets; Report IEA PVPS T1-29: 2016." International Energy Agency (IEA): Paris, France.

Burger, B., \& Rüther, R. (2006). Inverter sizing of grid-connected photovoltaic systems in the light of local solar resource distribution characteristics and temperature. Solar Energy, 80(1), 32-45. doi:10.1016/j.solener.2005.08.012

Camps, X. et al., 2015. Contribution to the PV-to-inverter sizing ratio determination using a custom flexible experimental setup. Applied Energy, 149, pp.35-45. Available at: http://dx.doi.org/10.1016/j.apenergy.2015.03.050.

Chen, S., Li, P., Brady, D., \& Lehman, B. (2013). Determining the optimum grid-connected photovoltaic inverter size. Solar Energy, 87, 96-116. doi:10.1016/j.solener.2012.09.012

EPIA European Photovoltaic Industry Association. (2014). "Global market outlook for photovoltaics 2014-2018." Brussels, Belgium.

Faranda, R., Hafezi, H., Leva, S., Mussetta, M., \& Ogliari, E. (2015). The Optimum PV Plant for a Given Solar DC/AC Converter. Energies, 8(6), 4853-4870. doi:10.3390/en8064853

Good, J., \& Johnson, J. X. (2016). Impact of inverter loading ratio on solar photovoltaic system performance. Applied Energy, 177, 475-486. doi:10.1016/j.apenergy.2016.05.134

Holmes, D. Grahame, and Thomas A. Lipo. (2003). Pulse width modulation for power converters: principles and practice. John Wiley \& Sons,.

Honrubia-Escribano, A., Ramirez, F. J., Gómez-Lázaro, E., Garcia-Villaverde, P. M., Ruiz-Ortega, M. J., \& ParraRequena, G. (2018). Influence of solar technology in the economic performance of PV power plants in Europe. A comprehensive analysis. Renewable and Sustainable Energy Reviews, 82, 488-501. doi:10.1016/j.rser.2017.09.061

Masters, G. M. (2013). Renewable and efficient electric power systems. John Wiley \& Sons.

Jatoi, A. R., Samo, S. R., \& Jakhrani, A. Q. (2018). Influence of Temperature on Electrical Characteristics of Different Photovoltaic Module Technologies. International Journal of Renewable Energy Development, 7(2), 85-91. doi:10.14710/ijred.7.2.85-91

Mohan, N., \& Undeland, T. M. (2007). Power electronics: converters, applications, and design. John Wiley \& Sons

Notton, G., Lazarov, V., \& Stoyanov, L. (2010). Optimal sizing of a grid-connected PV system for various PV module technologies and inclinations, inverter efficiency characteristics and locations. Renewable Energy, 35(2), 541554. doi:10.1016/j.renene.2009.07.013 
Omar, M. A. \& Mahmoud, M. M. (2018). Economic evaluation of residential grid connected PV systems based on Net-Metering and Feed-in-Tariff schemes in Palestine. International Journal of Renewable Energy Research (IJRER), 8(4), 21062115.

Omar, M. A., \& Mahmoud, M. M. (2018). Grid connected PVhome systems in Palestine: A review on technical performance, effects and economic feasibility. Renewable and Sustainable Energy Reviews, 82, 2490-2497. doi:10.1016/j.rser.2017.09.008

Omar, M. A., \& Mahmoud, M. M. (2019). Design and Simulation of a PV System Operating in Grid-Connected and StandAlone Modes for Areas of Daily Grid Blackouts. International Journal of Photoenergy, 2019, 1-9. doi:10.1155/2019/5216583

Omar, M. A., \& Mahmoud, M. M. (2019). Temperature impacts on the performance parameters of grid-connected PV systems based on field measurements in Palestine. IET Renewable Power Generation, 13(14), 2541-2548. doi:10.1049/ietrpg.2018.6281

Peippo, K., \& Lund, P. D. (1994). Optimal sizing of grid-connected PV-systems for different climates and array orientations: a simulation study. Solar Energy Materials and Solar Cells, 35, 445-451. doi:10.1016/0927-0248(94)90172-4

Peippo, K., \& Lund, P. D. (1994). Optimal sizing of solar array and inverter in grid-connected photovoltaic systems. Solar Energy Materials and Solar Cells, 32(1), 95-114. doi:10.1016/0927-0248(94)90259-3

Rodrigo, P. M., Velázquez, R., \& Fernández, E. F. (2016). DC/AC conversion efficiency of grid-connected photovoltaic inverters in central Mexico. Solar Energy, 139, 650-665. doi:10.1016/j.solener.2016.10.042

Sánchez-Carbajal, S., \& Rodrigo, P. M. (2019). Optimum Array Spacing in Grid-Connected Photovoltaic Systems considering Technical and Economic Factors. International Journal of Photoenergy, 2019, 1-14. doi:10.1155/2019/1486749

Jatoi, A. R., Samo, S. R., \& Jakhrani, A. Q. (2020). Performance Evaluation of Various Photovoltaic Module Technologies at Nawabshah Pakistan. International Journal of Renewable Energy Development, 10 (1), 97-103, doi: 10.14710/ijred.2021.32352

Santiago, I., Trillo-Montero, D., Moreno-Garcia, I. M., PallarésLópez, V., \& Luna-Rodríguez, J. J. (2018). Modeling of photovoltaic cell temperature losses: A review and a practice case in South Spain. Renewable and Sustainable Energy Reviews, 90, 70-89. doi:10.1016/j.rser.2018.03.054

Premkumar, M., Kumar, C., \& Sowmya, R. (2020). Mathematical Modelling of Solar Photovoltaic Cell/Panel/Array based on the Physical Parameters from the Manufacturer's Datasheet. International Journal of Renewable Energy Development, 9(1), 7-22. doi:10.14710/ijred.9.1.7-22

Wang, H. X., Muñoz-García, M. A., Moreda, G. P., \& AlonsoGarcía, M. C. (2018). Optimum inverter sizing of gridconnected photovoltaic systems based on energetic and economic considerations. Renewable Energy, 118, 709-717. doi:10.1016/j.renene.2017.11.063

(C) 2021. This article is an open access article distributed under the terms and conditions of the Creative Commons AttributionShareAlike 4.0 (CC BY-SA) International License (http://creativecommons.org/licenses/by-sa/4.0/) 